\title{
STUDENTS' PERCEPTION OF GROUP WORK AND KNOWLEDGE BUILDING IN AN ECONOMICS UNIT
}

\author{
Heng Kiat Sing ${ }^{1}$, Philip Nuli Anding ${ }^{2}$, Tan Kock Wah ${ }^{3}$ \\ ${ }^{1}$ Swinburne University of Technology Sarawak Campus, Malaysia \\ ${ }^{2,3}$ Universiti Malaysia Sarawak, Malaysia
}

\begin{abstract}
The purpose of this study is to examine students' perception of group work and knowledge building in an economics unit. Even though economics is a required subject for most business courses in higher education, past studies have shown that students perceived economic concepts as too abstract to understand and irrelevant to the real world. A qualitative research approach was chosen, using semi-structured face-to-face focus groups and/or individual interviews with forty-six business students who voluntarily participated in this study. The research results revealed that students have either a positive or negative perception of group work and knowledge building experience. Furthermore, this study found out that students who work in groups are able to demonstrate their ability in making economic concepts relevant by connecting the concepts to the real world if there is an on-going collaborative effort among team members. Guidance from the lecturer and team members could support some students particularly those who came from high school to tertiary learning, and where this is their first exposure to group work that deals with the complexities of real world events. The results presented may facilitate improvements in group work and increase the likelihood of knowledge building in economics subjects.
\end{abstract}

Keywords: Group Work, Knowledge Building, Collaborative Learning, Economics

\section{Introduction}

A primary concern in higher education is that graduates are expected to acquire knowledge and skills so that they are able to develop competence in continuous learning and problem solving in real life situations. Economics is a required subject for most business courses in tertiary learning. A diverse group of students poses a challenge for economics lecturers not only in terms of determining the relevant subject-specific skills to be embedded in the subject, but also in deciding the range of generic skills that the students will learn and later enable them to enhance their employment opportunities (Forsythe, 2010). Zlatkin-Troitschanskaia et al. (2016) reviewed past studies and state that the importance of economic knowledge in higher education has increased significantly not only in business but also in law and engineering courses at the international level.

\section{Background of the study}

This study researched and reported on students' perception of group work and knowledge building on group assignment that is related to economics in the business environment. The aim of this group assignment is to expose students to different market structures so that students will understand the behaviour of firms by examining and comparing businesses from a similar industry. In this study, group work refers to students work together to complete a written report whereas knowledge-building is defined as the "production and continual improvement of ideas of value to a community" (Scardamalia and Bereiter, 2003, p.1371) that is students learn how to continually improve ideas among group members. 


\section{Review of related literature}

Group work provides chances for students to negotiate meaning, manipulate ideas with others and reflect upon their learning (Fraser and Deane, 1997). Small group structures help distribute the cognitive load among the members of the group. This happens by taking advantage of group members' distributed expertise. Discussion among team members activates relevant prior knowledge and facilitates the processing of new information (Hmelo-Silver, 2004). This means that each member's efforts are required and indispensable for group success. Thus each member has a unique contribution to make to the joint effort because of the availability of resources, roles, and task responsibilities (Johnson and Johnson, 1999).

Participants through their collaborative interactions within a social and environment context (King et al. 2010; Yew et al. 2011) build knowledge. Bruffee (1995) states that the collaborative learning not only helps students become autonomous, articulate, and socially and intellectually mature, it also helps students learn the issues significantly due to a discipline-based inquiry process. Learners are able to construct meaning and knowledge, and identify the course of learning through active participation in individual and social activities (Biggs, 1996). Theoretically, the hierarchies of the building of knowledge in an economics subject starts from mastering the basic economic concepts to attaining higher-ordered thinking, creativity and synthesis of knowledge (Steinemann, 2003; Walstad, 2001). It is assumed that if students understand the subject content, they will be able to retrieve meaning from it and build interconnectivity between related concepts since "individuals are active in the reconstruction of the messages and meanings of assessments" (Sambell and McDowell, 1998, p.391).

With research and learning carried out in groups, students can learn how peer learning enforces knowledge and how group interaction allows deliberation and the exchange of information. Team members share responsibility for the overall advancement of knowledge in the team. This is consistent with the socio-cultural approach, the view of learning focuses on collaborative knowledge building and is an ongoing activity at the group level (Arvaja, 2005; Arvaja et al. 2007).

\section{Purpose of the study}

In previous studies, students have stated that economic concepts are too abstract to understand and they perceive these concepts as irrelevant to the real world (Islam, 2011; Reimann, 2004). Furthermore, studies in economics research (Tang, 2003; Tang and Robinson, 2004) have consistently shown that students lack the skill or ability to apply economic concepts to real world problems. Despite a great amount of writing devoted to introducing and integrating group work that deals with real problems to engage student learning (Forsythe, 2010; Goodman, 2010; Guest, 2012), there remains a paucity of evidence on the content and nature of knowledge building that takes place in collaboration between students.

Hence this study aims to examine students' perception of group work and knowledge building in an economics unit. Also, this study is relevant to higher education government policy in Malaysia because economics is an elective subject in secondary school, but is classified as a compulsory subject for all pre-university and undergraduate business studies (Khoo and Abdul, 2013). This study was conducted in the context of a naturalistic educational context, that is in a higher learning institution, so the process of knowing should be highly valued (Brownlee et al. 2009). 


\section{Research methodology}

A qualitative research approach was chosen, using semi-structured face-to-face focus groups and/or individual interviews lasting up to one hour. The purpose of the focus group interviews is to get collective views on a group of people, normally three to five members in a group. The individual student interviews and focus group interviews were organized separately. Direct quotations from interviews are a basic source of raw data in qualitative inquiry that could reveal respondents' depth of emotion, the ways they have organized their world, their thoughts about what happened, their experiences, and their basic perceptions (Patton, 2002) will be presented in the findings and discussion section. For ethical reasons, all the names used in this study are pseudonyms.

Purposive sampling was used in this study in selecting information-rich cases for in-depth study. Patton (2002, p. 230) states that, "Studying information-rich cases yields insights and in-depth understanding rather than empirical generalization." The participants were recruited from the course of Foundation of Arts in a private university in Sarawak. The criterion for participant selection was that participants were business students who enrolled for an introductory economics unit whereby this unit involved group work and group assessment. Fifty business students attended a briefing that was conducted by the researcher. After the briefing, a total of forty-six students expressed their willingness to participate in this study.

\section{Findings and discussion}

The research results reveal that students have either a positive or negative perception of group work and knowledge building experience.

\section{Students' perceptions about their experiences with group work}

The majority of the participants $(n=33)$ perceived their experience with their group work positively. Results reveal that students who found the experience of working in groups positive were more likely to reveal that they were satisfied with their team members and team leaders. Besides that, they revealed that they were content with the way that meetings were conducted in their groups. They also perceived that their interpersonal relationship with their team members as good and pleasant. In addition to that, they enjoyed the field work that they participated in. They identified that with the exposure to this group assignment, they have gained knowledge on the current economy, background of the organization, how to do business, preparing a report, planning the allocated tasks, and they had opportunities to share ideas among team members. This means that in certain circumstances ideas proposed by some students were taken over and expanded on by others. In this way, the cycles of discussion contributed both to the diffusion of ideas in the group as well as to the expansion of knowledge (Elbers and Streefland, 2000).

Students who had an unpleasant experience with their group work expressed that they were dissatisfied with the task allocated in the group assignment, field work experience, and interpersonal relationship among team members. Students expressed concerns that they did not receive proper guidance from seniors. Seniors are perceived by juniors as experts to guide them in their discipline; juniors are ordinary group members who perceived themselves as novices in their discipline. Hence, the guidance provided by seniors is greatly needed by juniors. Apparently this did not happen in some groups. Besides that, communication barriers also caused an unpleasant experience for some students. Students were not able to familiarize themselves with each other in a short period of time when members come from diverse language and cultural backgrounds so it was difficult "to expect newly formed groups with a substantial degree of cultural diversity to be able to solve problems very effectively" (Watson et al. 1993, p.598). 


\section{Student perceptions about their experiences with knowledge building}

Based on student narrative descriptions, it is most likely that a positive group work experience may lead to a positive knowledge building experience. This is evidenced in some participants, like G, H, J and R, where they explained their positive experience in knowledge building. However, we cannot deny the presence of negative group work experience that may prohibit students to engage in knowledge building.

A participant, J, highlighted the importance of 'understanding' in her knowledge building experience. This signifies that in group work, students take responsibility for advancing the group's understanding as they ask questions and built on each other's thinking to construct collaborative explanations (HmeloSilver and Barrows, 2008). This also confirms that if group assessments are employed correctly, it is undoubtedly they have the potential to promote better student interaction and understanding and allow a sharing of different views and knowledge (Strauss and Alice U, 2007).

"Without understanding, we cannot complete this task, we don't understand what economics is; we cannot come up with our own sentences or otherwise you know people would say we plagiarize other people's work. I think it is all based on understanding, you have to understand the economic terms." (Participant J, individual interview on $20^{\text {th }}$ July 2016 at $1 \mathrm{pm}$ )

Another participant, R, used the term 'communication' to illustrate his knowledge building experience. This finding is consistent with that of Jang (2007, p. 68) who found that "talk becomes a key component of knowledge construction and validation."

"For me (it) is communication. It is because we have to talk to each other to know what others are thinking and some just keep quiet, so we try to talk to them to get to know each other so we can know and do it together." (Participant R, focus group interview on $20^{\text {th }}$ July 2016 at $2 \mathrm{pm}$ )

Participants such as $\mathrm{G}$ and $\mathrm{H}$ relate their knowledge building experience with continuous improvement. Participant G shared that her experience is like "Climb the staircase. Improve myself one by one and increase my knowledge" (Focus group interview on $21^{\text {st }}$ July 2016 at 1pm). Another participant, H also had the same experience and used 'Kaizen' to describe it. "When I work with the team members, (we) make mistakes and improve on it ... know and learn something new from the interview, marketing strategy, how to attract customers, the knowledge could be used in the future if I want to operate a business" (Individual interview on $19^{\text {th }}$ July 2016 at 12 noon). This finding is consistent with the analysis of collaborative learning that revealed patterns of repetition and reconstruction of ideas in groups that foster the circulation, improvement and acceptance of knowledge (Elbers and Streefland, 2000).

It is important to note that two participants expressed their knowledge building experience as 'scared' and one participant expressed 'worried' for her experience. Four participants even mentioned that their knowledge building experience is 'stress.' Their experiences were caused by unclear expectations of the group assignment, overwhelmed with the workload allocated, limited assistance and guidance by senior, and team members who were not proactive in completing allocated tasks. 
"As a leader, you have to do the research and tell them [team members] what to do. Everyone will come after me. My senior is not helping at all. Keep asking questions." (Participant N, focus group interview on $21^{\text {st }}$ July 2016 at $1 \mathrm{pm}$ )

Due to their unpleasant experience in knowledge building, they wish that their team members could have been more responsible in their work and there should have been better coordination in work allocated.

"Because the team members seem like (they are) doing their own work ... I don't know how to describe the situation." (Participant W, focus group interview on 18th July 2016 at $11 \mathrm{am}$ )

Throughout this group work and knowledge building experience, students revealed that they were able to identify economic concepts and relate these concepts to economic events. Table 1 (below) presents the excerpts from interview responses that are related to economic events. Participants derived economic concepts such as demand and supply for goods and service, the impact of implementation of Goods and Services Tax (GST) in Malaysia, market opportunities and real world events. This shows that students were able to demonstrate their ability in making these economic concepts relevant and meaningful by connecting them to real world events when completing this group assignment, particularly for those participants who have positive group work and knowledge building experience.

Table 1 Excerpts from interview responses that are related to economic events

$\begin{array}{lcc}\text { Economic concepts and excerpts } & \text { Participant's group work } & \text { Participant's knowledge building } \\ \text { from interview responses } & \text { experience } & \text { experience }\end{array}$

Demand and supply for goods

and service

\begin{tabular}{|c|c|c|}
\hline $\begin{array}{l}\text { When the university is "having } \\
\text { [sic]" semester break, the café }\end{array}$ & Positive & Positive \\
\hline $\begin{array}{l}\text { "nearby [sic]" the off-campus } \\
\text { hostel didn't prepare so much } \\
\text { dishes due to a low demand. }\end{array}$ & "We divide the tasks." & "Amazing" \\
\hline $\begin{array}{l}\text { (Participant } S \text {, focus group } \\
\text { interview on } 18^{\text {th }} \text { July } 2016 \text { at } \\
3 \mathrm{pm} \text { ) }\end{array}$ & & \\
\hline
\end{tabular}

The demand and supply

for "Thai sauce" [a savory sauce] chicken rice. The cafeteria runs

Positive Positive out of this ingredient in preparing this cuisine.

(Participant J, individual interview on 20th July 2016 at $1 \mathrm{pm})$ 
Heng Kiat Sing, Philip Nuli Anding and Tan Kock Wah / Student's Perception of Group Work and Knowledge Building in an Economics Unit

\begin{tabular}{l}
\hline $\begin{array}{l}\text { The demand for bubble milk tea } \\
\text { "at [sic]"this town was affected }\end{array}$ \\
$\begin{array}{l}\text { by food poisoning incidents that } \\
\text { happened in Taiwan because one }\end{array}$ \\
$\begin{array}{l}\text { of the main ingredients in } \\
\text { preparing the drink is tapioca } \\
\text { pearls. }\end{array}$ \\
$\begin{array}{l}\text { (Participant K, focus group } \\
\text { interview on 20th July } 2016 \text { at }\end{array}$ \\
4pm)
\end{tabular}

Implementation of Goods and

Services Tax (GST)

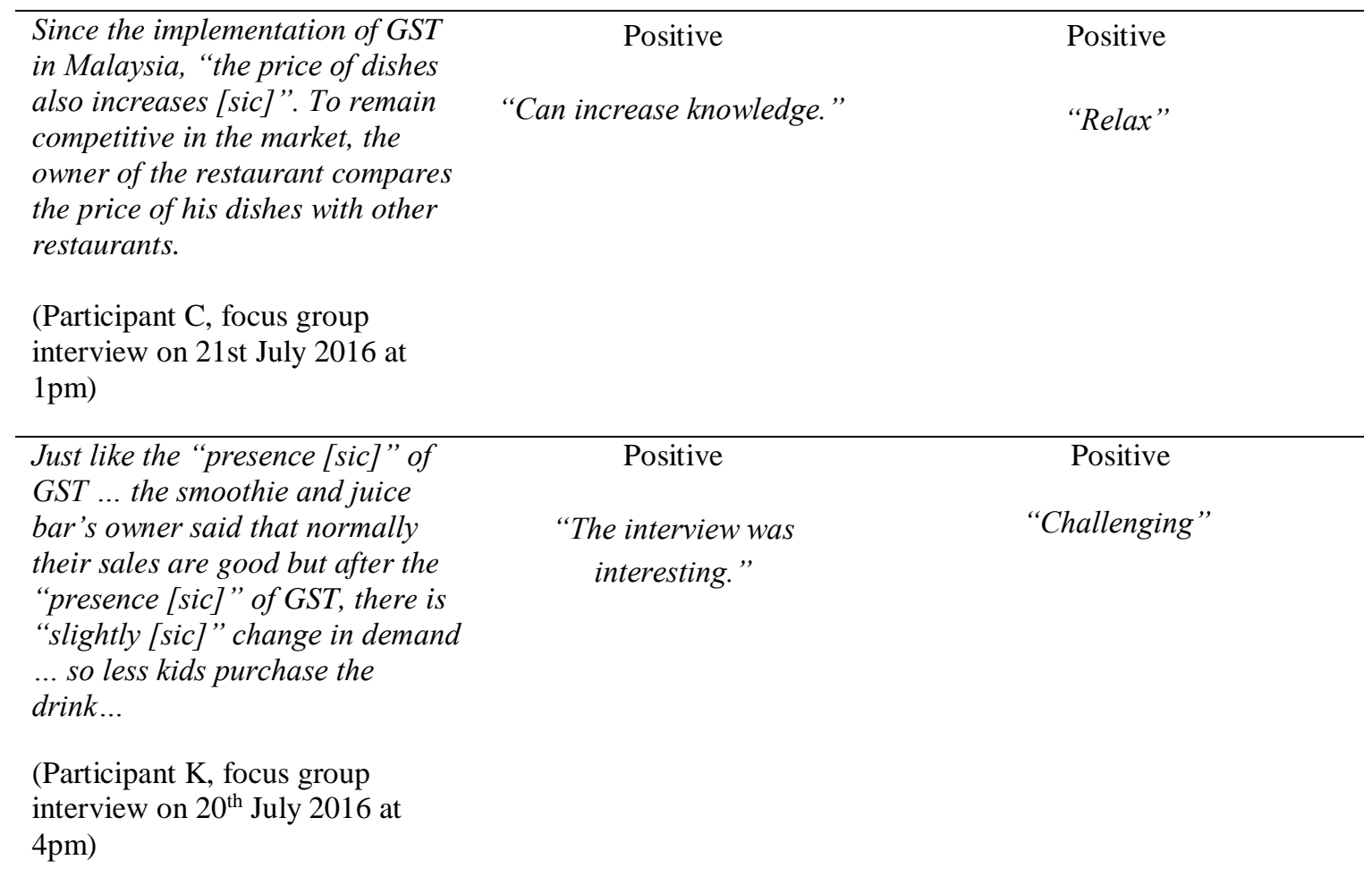

\begin{tabular}{lcc}
\hline Market opportunities & & \\
& & \\
\hline The hardware business "is & Positive & Negative \\
operating [sic]" in an open & "Can go for the & "Scared" \\
market. The owner of the & interview." & \\
hardware shop also involves in & & \\
$\begin{array}{l}\text { construction industry to diversify } \\
\text { his business. }\end{array}$ & & \\
(Participant P, focus group & & \\
interview on 21st July 2016 at & & \\
1 pm) & & \\
\hline
\end{tabular}




\begin{tabular}{lcc}
\hline $\begin{array}{l}\text { I learn that this beverage and } \\
\text { food outlet "is [sic]" a little bit } \\
\text { hard to penetrate the market }\end{array}$ & Positive & Negative \\
because in this town, we really & "The interview was also & "Tired" \\
like low cost... & interesting." & \\
(Participant D, focus group & & \\
interview on 20th July 2016 at \\
4pm)
\end{tabular}

In order to facilitate the process of group work and improve knowledge building, more inclusive practices, for example a briefing on group work, is recommended so that students are involved in the group process and the confidence of less assertive students can be improved. Also, there should be sufficient time for students to be pre-taught how to form and maintain workable groups and strategies to help them deal with conflicts (Strauss \& Alice U, 2007). Furthermore, for some students where this is their first exposure to a group assignment that deals with the complexities of real world events, guidance is needed from the lecturer, team leaders, and members. Guidance from the lecturer could support students when transiting from high school to tertiary learning. The findings of this study are important in planning group work and laying the groundwork for knowledge building experiences. Students' views on negative group work and knowledge building experience need to be canvassed to bring about improved understanding and implementation of group work in the future.

\section{Conclusion}

This study has explored and revealed students' perception of group work and knowledge building in an economics unit. The economic concepts that derived by students are closely related to economic events. The results presented here may facilitate improvements in the group work and increase the likelihood of knowledge building. In order to find more congruence and achieve their shared goals, students have to understand that they do not learn in a vacuum and their learning is always situated within a social cultural context. Based on student narrative descriptions, it is most likely that a positive group work experience may lead to a positive knowledge building experience. However, we have to take into account the presence of negative group work experience that may prohibit students to engage in knowledge building effectively so that they can apply what they have learnt in understanding real-world events. 


\section{Acknowledgements}

We would like to thank the students who volunteered to participate in this study. We also wish to thank the Dean, course coordinator and lecturer for the course of Foundation of Arts in the private university in Sarawak for their collaboration in conducting this study.

\section{References}

Arvaja, M., 2005, Collaborative knowledge construction in authentic school contexts. Jyväskylä: Institute for Educational Research, University of Jyväskylä.

Arvaja, M., Salovaara, H., Ha"kkinen, P., and Sanna, J., 2007, Combining individual and group-level perspectives for studying collaborative knowledge construction in context. Learning and Instruction, 17, 448459.

Biggs, J., 1996, Enhancing teaching through constructive alignment. Higher Education, 32, 347-364.

Brownlee, J. M., Walker, S., Lennox, S. P., Exley, B. E., and Pearce, S. M., 2009, The first year university experience: Using personal epistemology to understand effective learning and teaching in higher education. Higher Education, 58(5), 599-618.

Bruffee, K. A., 1995, Sharing our toys: Cooperative learning versus collaborative learning. Change(January/February), 12-18.

Elbers, E., and Streefland, L., 2000, Collaborative learning and the construction of common knowledge. European Journal of Psychology of Education, XV(4), 479-490.

Forsythe, F., 2010, Problem-based learning. Retrieved June 8, 2014, from http://www.economicsnetwork.ac.uk/handbook/printable/pbl2.pdf

Fraser, S., and Deane, E., 1997, Why open learning? Australian Universities' Review, 1, 25-31.

Goodman, R. J., 2010, Problem-based learning: merging of economics and mathematics. Journal of Economics and Finance, 34, 477-483.

Guest, R., 2012, The case for integrating accounting, finance, and economics in teaching the GFC through a problem-based learning approach. Journal of Business Ethics Education, 9, 11-24.

Hmelo-Silver, C. E., 2004, Problem-based learning: What and how do students learn? Educational Psychology Review, 16(3), 235-266.

Hmelo-Silver, C. E., and Barrows, H. S., 2008, Facilitating collaborative knowledge building. Cognition and Instruction, 26, 48-94.

Islam, S., 2011., Teaching introductory economics to students of different majors. Proceedings of American Society of Business and Behavioural Science, 18(1), pp. 877-885. Retrieved June 17, 2014, from http://asbbs.org/files/2011/ASBBS2011v1/PDF/I/IslamS.pdf. 
Jang, S-J., 2007, A study of students' construction of science knowledge: Talk and writing in a collaborative group. Educational Research, 49 (1), 65-81.

Johnson, D. W., and Johnson, R. T., 1999, Learning together and alone: Cooperative, competitive and individualistic learning (5th ed.). Massachusetts: Allyn and Bacon.

Khoo, Y. Y., and Abdul, G. K. A., 2013, Learning in group: The effectiveness of collaborative problem solving on pre-university students. Human and Social Science Research, 1(2), 105-111.

King, S., Greidanus, E., Carbonaro, M., Drummond, J., Boechler, P., and Kahlke, R., 2010, Synchronous problem-based e-learning (ePBL) in interprofessional health science education. Journal of Interactive Online Learning, 9(2), 133-150.

Patton, M. Q., 2002, Qualitative research and evaluation methods (3rd ed.). Thousand Oaks, CA:_Sage Publications.

Reimann, N., 2004, First-year teaching-learning environments in economics. International Review of Economics Education, 3(1), 9-38.

Sambell, K., and McDowell, L., 1998, The construction of the hidden curriculum: Messages and meanings in the assessment of student learning. Assessment and Evaluation in Higher Education, 23 (4), 391-402.

Scardamalia, M., and Bereiter, C., 2003, Knowledge building. In J. W. Guthrie, Encyclopedia of education (2nd ed., pp. 1370-1373). New York, NY: Macmillan.

Steinemann, A., 2003, Implementing sustainable development through problem-based learning: Pedagogy and practice. Journal of Professional Issues in Engineering Education and Practice, October, 216-224.

Strauss, P., and Alice U., 2007, Group assessments: Dilemmas facing lecturers in multicultural tertiary classrooms. Higher Education Research \& Development, 26(2), 147-161.

Tang, T., 2003, Understanding students' misunderstanding in economics. Economic Analysis \& Policy, 33(1), 157-171.

Tang, T., and Robinson, T., 2004, The effects of introductory economics course on students' beliefs and aptitudes in economics. Australasian Journal of Economics Education, 1(2), 199-222.

Walstad, W. B., 2001, Improving assessment in university economics. Journal of Economic Education, Summer, 281-294.

Watson, W. E., Kumar, K., and Michaelsen, L. K., 1993, Cultural diversity's impact on interaction process and performance: Comparing homogenous and diverse task groups. Academy of Management Journal, 36(3), 590602.

Yew, E. H., Chng, E., and Schmidt, H. G., 2011, Is learning in problem-based learning cumulative? Advances in Health Sciences Education, 16, 449-464.

Zlatkin-Troitschanskaia, O., Schmidt, S., Brückner, S., Förster, M., Yamaoka, M., and Asano, T., 2016, Macroeconomic knowledge of higher education students in Germany and Japan - a multilevel analysis of contextual and personal effects. Assessment \& Evaluation in Higher Education, 41(5), 787-801. 